С.С. Войтенко ${ }^{1}$ О.О. Бабич ${ }^{2}$

${ }^{1}$ Державне підприємство “Харківський регіональний науково-виробничий иентр стандартизаиії, метрології та сертифікаиії”, Харків

${ }^{2}$ Харківський національний університет Повітряних Сил ім. І. Кожедуба, Харків

\title{
МЕТОД ПЛАНУВАННЯ ТЕХНІЧНОГО ОБСЛУГОВУВАННЯ I ВІЙСЬКОВОГО РЕМОНТУ ОЗБРОЄННЯ ТА ВІЙСЬКОВОЇ ТЕХНІКИ В СУЧАСНИХ УМОВАХ
}

В статті розглядається підхід до побудови комплектів уніфікованих засобів технічного обслуговування $і$ військового ремонту. Виходячи з иього запропоновано метод планування технічного обслуговування $i$ військового ремонту озброєння та військової техніки з урахуванням застосування збройних сил в сучасних умовах. Цей метод сприятиме автоматизації і логістичній підтримці при плануванні використання за призначенням як існуючої системи військового ремонту, так і при застосуванні перспективних комплектів уніфікованих засобів технічного обслуговування і військового ремонту.

Ключові слова: уніфіковані засоби, технічне обслуговування, військовий ремонт, озброєння та військова техніка, діагностично-ремонтний комплекс.

\section{Вступ}

Постановка проблеми. Уряд України визначив основні напрями розвитку озброєння та військової техніки (ОВТ) на довгостроковий період Г11. Відповідно до них виникає можливість впровадити єдині підходи шодо формування технологічного та науково-технічного набутку під час створення cvчасних зразків озброєння та військової техніки 3 vрахуванням потреб сектору безпеки і оборони держави. Це створює підгрунтя для розробки нових програм шодо розвитку озброєння та військової техніки та визначає орієнтир для вітчизняних підприємств оборонно-промислового комплексу в напрямку розвитку озброєння та військової техніки. Невід'ємною частиною цього постає питання технічного обслуговування і військового ремонту (ТО і ВР) цієї техніки.

На сьогодні, основна частина засобів планування технічного обслуговування і військового ремонту морально застаріла та не відповідає сучасним вимогам навіть для існуючого парку зразків озброєння та військової техніки. Вони мають обмеження 3 номенклатури складових частин, що ремонтуються, видам робіт, які проводяться при технічному обслуговуванню і військовому ремонту, що не дозволяє своєчасно та якісно виконати ці роботи в місцях виконання завдань угрупуванням військ (сил) [2]. Кількість і можливості спеціалізованих засобів, які є в наявності і можливо використовувати при розгортанні військових ремонтних органів, також не відповідають сучасним вимогам їх застосування, це показало застосування їх під час антитерористичної операції та операції Об'єднаних сил. До виконання військового ремонту постійно залучалися виїзні метрологічні групи [3], що вказує на неправильне планування питання технічного обслуговування і військового ремонту.

У зв'язку з цим проблема технологічної підтримки та планування технічного обслуговування i військового ремонту набула критичного характеру. 3 огляду на даний факт, в цілях забезпечення органів ТО і ВР ОВТ, необхідно спланувати розробку уніфікованих діагностично-ремонтних комплексів (ДРК), а також розробити метод планування ТО і ВР.

Аналіз останніх досліджень і публікацій. Питанням технічного обслуговування i військового ремонту присвячено багато робіт [4-8], слід зазначити, що все починається з технічної документації, а все інше направлено на скорочення витрат часу та ресурсів. Питання удосконалення та пропозиції щодо реформування системи контролю технічного стану зразків озброєння та військової техніки військових підрозділів розглядаються в [6-7]. В роботі [8] запропоновано методику розміщення метрологічних підрозділів, фактично це один із ДРК, який діє самостійно самостійно (для спрощення планування робіт цього ДРК на окремих напрямках контролю технічного стану озброєння та військової техніки присвячені роботи [9-10]. Дану методику можливо використовувати і для мобільних комплектів уніфікованих засобів технічного обслуговування і військового ремонту (КТР). В роботі [11] наводиться приклад моделюванню оборонних логістичних ланцюгів. В сучасних умовах застосування збройних сил, актуальності набувають питання не тільки стратегії застосування та удосконалення засобів технічного обслуговування і військового ремонту, а і пла- 
нування їх роботи (як існуючими засобами ТО і ВР, так і перспективними).

Метою статті $\epsilon$ розробка методу планування технічного обслуговування і військового ремонту розвитку озброєння та військової техніки для угрупування військ (сил). В даній статті пропонується підхід до автоматизації і логістичної підтримки при плануванні використання за призначенням як існуючої системи військового ремонту (СВР), так і з застосуванням перспективних комплектів уніфікованих засобів технічного обслуговування і військового ремонту.

\section{Виклад основного матеріалу}

Ефективність функціонування СВР ОВТ визначається складом іiі елементів на кожному із рівнів ешелонування, а також способом розподілу завдань між елементами різних рівнів. Елементами, які мають найбільший вплив на ефективність функціонування системи військового ремонту в цілому, є засоби проведення технічного обслуговування і військового ремонту. Потреба в заходах з ТО і ВР ОВТ планується 3 річних норм витрати ресурсів озброєння та військової техніки, термінів зберігання, встановленої періодичності технічного обслуговування і міжремонтних термінів експлуатації, планів бойової підготовки і результатів проведеного контролю технічного стану зразків озброєння та військової техніки та їх складових частин [12]. Необхідно визначити план застосування КТР, що забезпечить мінімізацію простоїв озброєння та військової техніки у зоні відповідальності, на да-ний час, при проведенні ООС. Комплекти уніфіко-ваних засобів технічного обслуговування і військо-вого ремонту повинні втілювати в собі передові технології, щоб замінити великий парк морально застарілих засобів технічного обслуговування і військового ремонту, вони мають стати ефективним інструментом підтримання високої бойової готовності озброєння та військової техніки [1].

Комплекти уніфікованих засобів технічного обслуговування і військового ремонту можуть включати типові діагностично-ремонтні комплекси:

“ДРК - $1\left(k_{1}\right)$ ” - модуль контролю, діагностики та ремонту типових замінних елементів;

“ДРК - 2( $\left.k_{2}\right)$ ” - модуль контролю, діагностики і ремонту систем електроживлення;

“ДРК - 3( $\left.k_{3}\right)$ ” - модуль дефектації і ремонту

(заправки) електромеханічних, механічних та гідравлічних вузлів і деталей, кондиціонерів, систем охолодження, пожежогасіння та життєзабезпечення зразків ОВТ;

“ДРК $-4\left(k_{4}\right)$ ” - модуль ремонту засобів пересування і зарядки акумуляторних батарей;

“ДРК $-5\left(k_{5}\right)$ ” - модуль відновлення засобів вимірювальної техніки;

“ДРК - 6( $\left.k_{6}\right)$ ” - модуль розміщення комплектів запасних частин, інструментів, приладдя і ремонтної документації;

“ДРК - $i\left(k_{i}\right)$ " - інші модулі.

У тому числі, необхідно зазначити, що модулі можливо застосовувати як окремо один від одного, так і в комплексі. Комплект уніфікованих засобів технічного обслуговування і військового ремонту пропонується використовувати для обладнання ремонтно-відновлювальних органів тактичного і оперативного-тактичного рівнів. Даний комплект повинен передбачати можливість розміщення, як в транспортних засобах так і в стаціонарних приміщеннях. Таким чином комплекти уніфікованих засобів технічного обслуговування і військового ремонту є складною технічною системою, ефективність якої залежить від характеристик іiі діагностично-ремонтних комплексів та від організації застосування, тобто розподілення в просторі і часі реалізації елементами системи своїх функцій (технічне обслуговування та військовий ремонт), що можна розглядати, як організоване управління цією системою. Обгрунтування раціонального порядку (вибір раціонального варіанту організації) технічного обслуговування і військового ремонту озброєння та військової техніки в умовах дії багатьох несприятливих факторів, характерних для сучасного етапу розвитку та застосування 3С України пов'язано із неабиякими труднощами. Можливі помилки і прорахунки можуть призвести до значних економічних втрат, недопустимому зниженню бойової готовності військ. Заходи, які передбачені для раціональної реалізації, повинні бути направлені на найбільш повне використання ресурсів кожної одиниці техніки, скорочення працевтрат та вартості технічного обслуговування і військового ремонту. Планування застосування комплектів уніфікованих засобів технічного обслуговування і військового ремонту здійснюється із потреб в ТО і ВР і 3 урахуванням стану ДРК та їх продуктивності. Ефективність планування застосування КТР достатньо в повному обсязі може бути оцінено терміном перебування зразка ОВТ в непрацездатному стані. В математичній постановці задачу можна сформулювати наступним чином [13]. Потрібно визначити план $(P)$ застосування КТР $(K)$, які забезпечують мінімізацію простоїв $(Z)$ ОВТ $(V)$ у зоні відповідальності:

$$
\begin{aligned}
& (P) Z(V \mid P(K, V \underset{P}{\longrightarrow} \min )) ; \\
& V \subseteq V_{k},
\end{aligned}
$$

де $V$ - складова ОВТ угрупування військ, яка планується на проведення ТО і ВР із застосуванням КТР в зоні його відповідальності; 
$K=\left\{k_{1}, k_{2}, \ldots, k_{7}\right\}-$ склад ДРК КТР;

$V_{k}$ - склад ОВТ у зоні відповідальності КТР.

Цільову функцію можна представити виразом:

$$
\begin{gathered}
Z(V \mid P(K, V))= \\
=\sum_{v \in V_{k}} \mathrm{Y}_{v}\left[t_{3}(V \mid P(K, V))-t_{n}(V \mid P(K, V))\right],
\end{gathered}
$$

де $t_{3}(V \backslash P)$ - час завершення заходів ТР зразка ОВТ $v \in V_{k}$

$t_{n}(V \backslash P(K, V))$ - час на який планується початок заходів ТР зразка ОВТ $v$;

$Y_{v}$ - вагові коефіцієнти важливості зразка озброєння та військової техніки $v \in V_{k}$.

Запланований час початку заходів ТО і ВР визначається як результат моніторингу технічного стану зразків ОВТ та їх складових частин (в тому числі під час підконтрольної експлуатації [14]) для визначення реального часу початку цих заходів.

Реальний час початку заходів ТО і ВР визначається можливостями та завантаженням ДРК, які залучаються до виконання заходів по мірі закінчення таких на попередніх зразках ОВТ:

$$
t_{n}^{k}(V \mid P(K, V))=\max \left(\left(t_{n}\right), t_{n p}(k, v)\right),
$$

де $t_{n p}(k, v)$ - час прибуття ДРК $k$ до зразку ОВТ $v$.

Час прибуття ДРК представлено формулою:

$$
\begin{gathered}
t_{\text {пр }}(k, v)=t_{\text {в }}(k)+ \\
+\tau^{\partial в}\left(d\left(v^{\prime}\right), d(k)+\tau_{\text {компл }}(k)+\tau^{\partial в}\left(d(k), d\left(v^{\prime}\right)\right)\right),
\end{gathered}
$$

де $t_{b}(k)$ - час закінчення попередніх робіт ДРК $k \in K$;

$$
\begin{aligned}
& d(k) \text { - пункт дислокації ДРК } k \in K \\
& d(v) \text { - пункт дислокації ОВТ } v \in V ; \\
& \tau^{\partial \theta}\left(d(k), d\left(v^{\prime}\right)\right) \text { - час руху з пункту попере- }
\end{aligned}
$$
дніх робіт $d\left(v^{\prime}\right)$ до пункту дислокації ДРК $k \in K$;

$\tau_{\kappa}(k)$ - час укомплектування обладнанням ДРК $k \in K$ для робіт.

3 урахуванням викладеного час завершення заходів ТО і ВР зразка ОВТ V можна представити виразом:

$$
\begin{aligned}
t_{n}(V \mid P(V, K))= & \max _{k \in K}\left(t_{n}^{k}(V \mid P(V, K))+\tau(v, K)\right)+ \\
& +t_{\kappa n}(V \mid P(V, K)),
\end{aligned}
$$

де $\tau(v, k)$ - час робіт ДРК $k \in K$ на ОВТ $v \in V_{k}$;

$t_{\kappa n}(V \backslash P(V, K))$ - час комплексної перевірки працездатності зразка ОВТ $v \in V_{k}$, після проведення заходів ТР.

Вагові коефіцієнти $Y_{v}, v \in V_{k}$ можуть визначатись експертним методом з урахуванням характери- стик $x(v)$ зразка ОВТ, його місця і ролі в угрупуванні військ (сил). При виборі в якості $Y_{v}$ важливості зразка ОВТ, тобто $Y_{v}=c(v)$ цільова функція відображає втрати через неготовність ОВТ до бойового застосування, або необхідну надлишковість в зразках ОВТ для компенсації простоїв.

$$
P=\left\|t_{k v}\right\| v \in V_{k}, k \in K,
$$

де $t_{k v}$ - час початку робіт ДРК $k \in K$ при ТО і ВР озброєння та військової техніки.

Якщо ДРК $k \in K$ не залучаються до робіт, то припускаємо $t_{k v}=T_{n}$, де $\left[0 \ldots T_{n}\right]-$ інтервал планування. Складний характер цільової функції $Z$ не дозволяє застосовувати точні методи рішення задачі $(1,2)$, тому пропонується наближений алгоритм щодо іiі рішення. В основі алгоритму оптимізації плану $P(K, V)$ покладено принцип максимального зниження цільової функції $Z$ при кожному призначенні [13]. Метод включає наступний алгоритм.

1. Введення початкових даних:

$$
V, K, t_{B}(k), \tau(v, k), t_{n}(v) .
$$

2. Визначення наступного призначення:

$$
v^{*}=\arg \min _{v \in V} Z(v \mid P(v, K)) Z(v \mid P(K, V)) \text {. }
$$

3. Визначення часу виконання заходів ТР зразка ОВТ $v^{*}$.

$$
t_{3}\left(v^{*} \mid P\left(v^{*}, K\right)\right)
$$

4. Коригуємо стан ДРК, які застосовуються:

$$
\begin{aligned}
& t_{\text {oc } B}(K)=t_{n}^{k}\left(v^{*}\right)+\tau\left(v^{*}, K\right) ; \\
& d(k)=d\left(v^{*}\right) .
\end{aligned}
$$

5. Виключення $v^{*}$ з множини $V$ :

$$
V=V \mid\left\{v^{*}\right\} \text {. }
$$

6. Якщо $V \neq \varnothing$, то перехід до п. 2.

7. Завершення розрахунків. Друк результатів.

\section{Висновки}

Розроблена методика планування технічного обслуговування і військового ремонту озброєння та військової техніки для угрупування військ (сил). Запропоновано підхід до автоматизації і логістичної підтримки при плануванні використан-ня за призначенням як існуючої системи військового ремонту, так і з застосуванням перспективних комплектів уніфікованих засобів технічного обслуговування і військового ремонту.

При використанні розробленого методу планування технічного обслуговування і військового ремонту та застосування комплектів уніфікованих засобів технічного обслуговування і військового ремонту може бути отримано наступний ефект:

- збільшення продуктивності і функціональних 
можливостей по технічного обслуговування і військового ремонту зразків озброєння та військової техніки, що знаходяться в експлуатації;

- забезпечення відновлення ресурсу розвитку

озброєння та військової техніки;

- підвищення оперативності відновлення зразків озброєння та військової техніки і рівня їх бойової готовності;

- зменшення вартості експлуатації парку розвитку озброєння та військової техніки.

Напрямком подальших досліджень слід вважа- ти отримання кількісних показників від використання розробленого методу планування технічного обслуговування і військового ремонту та застосування комплектів уніфікованих засобів технічного обслуговування і військового ремонту. Для оцінки, можливо застосувати математичний апарат методики оцінювання ефективності функціонування системи логістичного забезпечення [15], використовуючи відповідні коефіцієнти нормативної ефективності комплектів уніфікованих засобів технічного обслуговування і військового ремонту.

\section{Список літератури}

1. Про схвалення Основних напрямів розвитку озброєння та військової техніки на довгостроковий період : Розпорядження Кабінету Міністрів України від 16 черв. 2017 р. № 398-p. URL: https://zakon.rada.gov.ua/laws/show/398-2017\%D1\%80\#Text (дата звернення: 22.04.2021).

2. Бабкін Ю. В., Оліфіренко В. С. Аналіз існуючих засобів технічного обслуговування та пропозиції щодо скорочення часу на технічне обслуговування бронетанкового озброєння та військової техніки у польових умовах. Інформаційні технології: наука, техніка, технологія, освіта, здоров'я : зб. тез. доп. XXVII Міжнародної наук.-практ. конф., 1517 трав. 2019 р. Харків : ХПI, 2019. С. 16. URL: http://repository.kpi.kharkov.ua/bitstream/KhPI-Press/44984/ 1/MicroCAD_2019_Babkin_Analiz_isnuiuchykh.pdf (дата звернення 18.03.2021).

3. Войтенко С. С., Кузнецов І. Б. Пропозиції щодо удосконалення планування в системі метрологічного забезпечення Збройних Сил України. Новітні технологї - для захисту повітряного простору : зб. тез. доп. ХІІ Міжнародної наук. конф. Харків : ХНУПС, 2016. С. 409-410. URL: http://www.hups.mil.gov.ua/assets/doc/science/conference/12/ section18.pdf (дата звернення 18.03.2021).

4. Застосування підрозділів та військових частин технічного забезпечення: в 2 книгах / Підрозділи технічного забезпечення / Копашинський С. А. та ін. Київ : МОУ, 2017. 136 с.

5. Застосування підрозділів та військових частин технічного забезпечення: в 2 книгах / Ремонтно-відновлювальна військова частина / Копашинський С. А. та ін. Київ : МОУ, 2017. 80 с.

6. Войтенко С. С., Герасимов С. В., Куценко В. В. Напрями удосконалення системи контролю технічного стану зразків озброєння та військової техніки. Наука і техніка Повітряних Сил Збройних Сил України. 2016. № 3(24). С. 127131. URL: http://www.hups.mil.gov.ua/periodic-app/article/17190 (дата звернення 18.03.2021).

7. Войтенко С. С., Мошаренков В. В. Пропозиції щодо реформування системи контролю технічного стану зразків озброєння та військової техніки. Метрологія, інформаційно-вимірювальні технології та системи : зб. тез доп. VII Міжнародної наук.-техн. конф. 18-19 лют. 2020 р. Харків, 2020. С. 19-20. https://doi.org/10.24027/2306-7039.1А.2020.193279.

8. Войтенко С. С., Бабич О. О., Мошаренков В. В. Методика визначення оптимального розміщення виїзних метрологічних підрозділів на прикладі проведення операції Об'єднаних сил. Системи озброєння $і$ військова техніка. 2020. № 2(62). C. 52-58. URL: https://journal-hnups.com.ua/index.php/soivt/article/view/332 (дата звернення 18.03.2021).

9. Теоретические базовые концепции для формирования критериев для измерения сигналов синтеза оптимальности для управления сложных радиотехнических систем технического состояния / Брацлавська А. Ю. та ін. Системи обробки інформації. 2017. № 5(151). C. 151-157. URL: http://www.hups.mil.gov.ua/periodic-app/article/18009/ukr (дата звернення 18.03.2021).

10. Герасимов С. В., Грідіна В. В. Методика обгрунтування номенклатури параметрів контролю радіотехнічних систем і призначення їх допустимих відхилень. Системи обробки інформації. 2018. № 2(153). C. 159-164. URL: http://www.hups.mil.gov.ua/periodic-app/article/18792 (дата звернення 18.03.2021).

11. Gallasch Guy E., J. Lilith. Modelling Defence Logistics Networks. International Journal on Soft-ware Tools for Technology Transfer. 2008. No. 1(10). P. 75-9. URL: http://citeseerx.ist.psu.edu/viewdoc/summary?doi=10.1.1.85.9536 (accessed 18.03.2021).

12. Основи організації експлуатації і ремонту озброєння та військової техніки / за ред. Мацько О.Й. Київ : НУОУ, 2018. $400 \mathrm{c}$.

13. Попов Ю. Д., Тюптя В. І., Шевченко В. І. Методи оптимізації. Київ : КНУ, 2003. 215 с. URL: http://www.cyb.univ.kiev.ua/library/books/popov-30.pdf (дата звернення 18.03.2021).

14. Інструкція з організації проведення підконтрольної експлуатації озброєння та військової техніки у Збройних Силах України : Наказ Міністра оборони України від 16 лист. 2018 р. № 578. URL: https://zakon.rada.gov.ua/ laws/show/z0277-19\#Text (дата звернення: 22.04.2021).

15. Наконечний О. В. Методика оцінювання ефективності функціонування системи логістичного забезпечення сил оборони держави. Наука $і$ техніка Повітряних Сил Збройних Сил Украйни. 2020. №1(38). С. 54-60. https://doi.org/10.30748/nitps.2020.38.06. 


\section{Відомості про авторів:}

\section{Войтенко Сергій Станіславович}

кандидат технічних наук доцент

інженер з метрології 2 категорії

Харківського регіонального науково-виробничого центру стандартизації, метрології та сертифікації,

Харків, Україна

https://orcid.org/0000-0003-4134-5964

\author{
Бабич Ольга Олегівна \\ науковий співробітник \\ Харківського національного університету \\ Повітряних Сил ім. І. Кожедуба, \\ Харків, Україна \\ https://orcid.org/0000-0003-1852-2395
}

Information about the authors:

Serhii Voitenko

Candidate of Technical Science Associate Professor

Metrology Engineer of the 2nd Category of the State Enterprise

"Kharkiv Regional Research and Production Center

for Standardization, Metrology and Certification",

Kharkiv, Ukraine

https://orcid.org/0000-0003-4134-5964

\author{
Olga Babych \\ Researcher \\ of Ivan Kozhedub Kharkiv National \\ Air Force University, \\ Kharkiv, Ukraine \\ https://orcid.org/0000-0003-1852-239
}

\title{
МЕТОД ПЛАНИРОВАНИЯ ТЕХНИЧЕСКОГО ОБСЛУЖИВАНИЯ И РЕМОНТА ВООРУЖЕНИЯ И ВОЕННОЙ ТЕХНИКИ В СОВРЕМЕННЫХ УСЛОВИЯХ
}

\author{
С.С. Войтенко, О.О. Бабич
}

В статье рассматривается подход построения комплектов унифицированных средств технического обслуживания и войскового ремонта. Предложен метод планирования технического обслуживания и войскового ремонта вооружения и военной техники с учетом современного применения вооруженных сил. Этот метод будет способствовать автоматизачии и логистической поддержке при планировании использования по назначению, как существующей системы войскового ремонта, так и при применении перспективных комплектов унифицированных средств технического обслуживания и войскового ремонта.

Ключевые слова: унифицированные средства, техническое обслуживание, войсковой ремонт, вооружение и военная техника, диагностический ремонтный комплекс.

\section{METHOD OF PLANNING MAINTENANCE AND MILITARY REPAIR OF WEAPONS AND MILITARY EQUIPMENT IN MODERN CONDITIONS}

\section{S. Voitenko, O. Babych}

The problem of technological support for maintenance and repair of military equipment has become critical. In order to provide maintenance and military repair of armaments and military equipment, it is planned to have unified repair and diagnostic systems and auxiliary modules. This article proposes an approach to automation and logistical support in planning the intended use of promising mobile military repairs and maintenance of armaments and military equipment being developed. The effectiveness of the system of military repair of weapons and military equipment is determined by the composition of its elements at each level of separation, as well as the method of distribution of tasks between the elements of different levels. The element that most significantly affects the efficiency of the military repair system as a whole is the means of maintenance and repair, namely a set of unified means of maintenance and military repair. The need for measures for maintenance and military repair of weapons and military equipment is planned from the annual consumption of weapons and military equipment, storage time, the established frequency of maintenance and maintenance of weapons and military equipment, combat training plans and results of combat training and results armaments and military equipment and their components. It is necessary to define a plan for the use of a set of unified means of maintenance and military repairs that minimize downtime of weapons and military equipment in the area of responsibility. The article proposes an approach to building sets of unified means of maintenance and military repairs. Based on this, a method of planning maintenance and military repair of weapons and military equipment, taking into account the use of armed forces in modern conditions. This approach will facilitate automation and logistical support in planning the intended use of both the existing military repair system and in the application of promising sets of unified means of maintenance and military repair.

Keywords: unified means of maintenance and military repair, weapons and military equipment maintenance, military repair, diagnostic repair complex. 